AGRICULTURE AND BIOLOGY JOURNAL OF NORTH AMERICA

ISSN Print: 2151-7517, ISSN Online: 2151-7525, doi:10.5251/abjna.2013.4.3.300.308

(C) 2013, ScienceHuß, http://www.scihub.org/ABJNA

\title{
To study ways to add a phosphorus on vegetative growth of wheat plants growing under conditions of Algeria
}

\author{
Gherroucha, $\mathrm{H}^{1}$; Bouchareb, $\mathrm{R}^{2 ;}$ Fercha, $\mathrm{A}^{3}$ and Larous, $\mathrm{L}^{4}$ \\ $1^{-2}$ Laboratory of Development and Evaluation of Plant Genetic Resources ,Department of \\ Biology and Ecology ,Faculty of natural sciences and life ,Mentouri University of Constantine \\ - Algeria \\ ${ }^{3}$, Department Of biology, University of Abbes Laghrour Khenchela, Algeria \\ ${ }^{4}$, Department Of biology, University Setif , Algeria
}

\begin{abstract}
Then a field experiment in two consecutive seasons on a farm in the Division lead to study the effectiveness of the added phosphorus spraying on the leaves and compare them added to the ground on the vegetative growth of wheat plants under conditions of Algeria, where you use three factors for phosphorus $\mathrm{P}_{0}$ - Ps - $\operatorname{Pr}$ (without adding phosphorus - affixed to the ground - added spray), respectively. and massage at 50 parts / million $\mathrm{P}_{2} \mathrm{O}_{5}$ on the image of super phosphate, and then added in two 3 / 2 amount by the Agriculture mixing with the soil and $3 / 1$ the remainder after 15 days of agriculture, was also used phosphorus spraying on the leaves concentration of $1 \%$ of the sodium phosphate mono $\mathrm{NaHPO}_{4}$ three periods after 30 - 35 - 40 days of agriculture, and selected two types of soil differ in physical and chemical characteristics, results showed the following: Increased the dry weight of shoot significantly by adding phosphorus to any of the methods for the treatment of comparison, regardless of the type of soil The addition of phosphorus in any of the methods to increase the number of leaves and the back in both two soil in the two phases of growth. The addition of phosphorus to the ground to the significant increase in total dry weight of roots and surpassed the values of dry weight of both shoots and roots in the soil of the first region than those in the soil of Talha. - The mutual influence between the two variables is statistically significantlncreased the total content of phosphorus in shoot dry any of the methods although the added Ground surpassed Added spraying on the leaves, but the same trend was observed for the dry weight of roots.
\end{abstract}

Key words: Spraying, Dressing, Wheat, Phosphorus.

\section{INTRODUCTION}

Wheat is the most important crop in various parts of the world it is considered the daily food source of most rich and poor people, because of its nutritive value, The element phosphorus is necessary for the plant needs in large quantities, where it enters in the composition of organic material, plant tissue, and the phosphate compounds, which are directly related to the process of breathing, and is essential in the transformation processes of carbohydrates in the plant, and the biosynthesis of fatty substances, it is also implicated in the growth of roots, and is necessary for cell division processes, and the growth fruiting of the plant. It is worthful to poit out that plants take their phosphorus from the soil as fertilizer. Fuehring (1973) and Brown et al. (2005) have mentioned that, the decrease of soluble phosphorus in the soil is due to the presence of several factors, which lead to a shift of phosphorus into insoluble form, such as the presence of calcium carbonate, and the rise of the $\mathrm{P}^{\mathrm{H}}$, as in the case of calcareous soils( Frei et al., 1964), It is also Known that, there are some factors that lead to the inability of plants to take up phosphorus from soil .However, a method has been used for spraying on the leaves to benefit from the possibility of plant to uptake elements through their Leaves. Malakondajah et al. (1981) and Velly (1978) have pointed that, this method hase a positive effect on plants growth under appropriate environmental conditions, The aim of this study is an attempt to Know effectiveness phosphorus spraying on Leaves and compare that added to the soil, on the growth of wheat plants under environmental conditions of Algeria .

MATERIALS AND METHODS The Experiment was carried out in plastic pots, $(12 \mathrm{~cm}$ long and $18 \mathrm{~cm}$ larg).They were filled with $2 \mathrm{~kg}$ of soil samples, 
brought from the El khroub [15 km east of the city of Constantine). The physical and chemical properties of two samples of soil have been estimated (table 1 ),( Richards,1954;Black, 1965)

The experiment in etuded 03Coefficients of $P$ as follow:

\section{_Without adding phosphorus}

_ Addition of phosphorus to the soil at $50 \mathrm{ppm} / \mathrm{P}_{2} \mathrm{O}_{5}$ as super phosphate, on two steps, 3 / 2 of the amount was added before and the sowing and the 3 / 1 was added after 15 days from sowing.

- Addition of phosphorus as spray on the leaves with the concentration of $1 \%$ sodium phosphate mono $\mathrm{NaHPO}_{4}$, added on three stages at $30-35$ and 40 days of cultivation.

- Two types of soil,were used ,from zone one and Talha (6 treatment with 4 replication) for each stage of growth. Esch pot was planted with 16 grains of wheat from class ENZA, and irrigated with distilled water until filled capacity .after germination plants were eased to 12 per pot.

Nitrogen and potassium were added to all pots, at the average of 100 ppm for $\mathrm{N}$ and 50ppm for $\mathrm{K} 2 \mathrm{O}$ as ammonium nitrate and potassium sulfate $\left.\left(\mathrm{NH}_{4}\right) \mathrm{NO}_{3}\right)$ - $\mathrm{K}_{2} \mathrm{SO}_{4}$ ), respectively.

plant samples were studied in two phases during the period of the experiment. First stage: after 45 days from sowing.

the following measurements were taken for each phase :

- The Number of leaves

- The number of back

Then the growing plants in each pot were removed and flooded in top water, and then the roots were washed well with running water, then with distilled water.

- The Fresh weight of shoots and roots was done firstly, thene the dry weight was calculated after drying plants in an electric oven at $75^{\circ} \mathrm{C}$. Samples of the plant shoots were pulverized and digested using a mixture of sulfuric acid and nitric $\mathrm{H}_{2} \mathrm{SO}_{4}$ $\mathrm{HNO}_{3}$ and $\mathrm{HClO}_{4}$ perchloric Acid( Johnson, 1959). The method of ascorbic acid was used as described by Frei et al. (1964) to estimate the phosphorus

\section{RESULTS AND DISCUSSION}

Table 1 shows some natural and chemical characteristics of the two types of soils they were considered as calcareous soils, where the total of carbonates was $(25 \%-30 \%)$ of the first region soil and Talha, espectively. Hilal et al (1973) noted that the soil whitch contains more than $8 \%$ carbonate is considered as calcareous. The electrical conductivity of both soils was found to be normal, (less than $2 \mathrm{~m}$ mhos / cm at $25^{\circ} \mathrm{C}$ ).

the $\mathrm{P}^{\mathrm{H}}$ is situated at the alkali light range, however ,it is slightly higher in the first region soil than that of Talha,this is goes with the rate of calcium carbonate in both soil .However, the content of organic matter in both soils is considered acceptable,kneed et al (2005) Van den. and Velly, J. (1978)

Table 2 shows that, The addition of phosphorus in any of the method used(adding to the ground or spraying on the(eaves) lead to an increase in the number of leaves in both soil samples.

At the first stage of growth for control treatment ,while there are no differences between the two methods of addition were obtained on the same trend in the second phase of growth, with the exception of superiority of the Added $P$ to the ground than the sprayed on in the case of Talha soil.also the addition of $P$ with any of the two methods lead increase of the number of tillers for the control treatment in both studied soils and in both phases of growth.

The fresh weight of shoot and roots was positively affected by adding phosphorus by any of the two methods. It was noted that, the is a superiority of the addition of phosphorus to the gound than that of spraying on leaves. More over, the first region showed superior value than that of Talha

Figure( 1 ) show the effect of studied treatment on the dry weight of both shoots and roots in the first stage of growth for the impact of phosphorus addition for any of the two methods resed compared to the control treatment where as the addition of phosphorus to the soil gave a significant increase in the total dry weight of roots.

for the soil type, and regardless of phosphorus treatment, the values of dry weight for both of shoots and roods in the soil of the first region were greater than that of Talha, soil ( Figure 1). Howover, the mutual influence between the two studied variables was statistically not significant .

it appears from the same figure that, the results obtained in the second phase were smilar to those obtained in the first phase of growth, except for the effect of mutual influence between the two studied variables on the dry weight of roodswhich was 
significant at the level of $5 \%$ on the second stage of growth .

in addition to that, the difference in dry weight of roots was statistically significant, when comparing , the two treatment of phosphorus addition to the soil of the first zone only, which does not appear in the soil of Telha .

in addition to that, the difference in dry weight in the control treatment without phosphorus was not significant, when the two soils were compared. there is no difference in the dry weight of roots of both soils ( the soil of first zone and Talha soil ). whereas, the difference of dry weight of both soils was significant in the case of addition of phosphorus, when it was sprayed on leaves.

Table $(3,4$ )and figure 2 showed that ,the rote of increase of dry weight of shoots and roots was very clear. In addition to that, table(5) and figure $(4,5)$ shon that ,the amendment of phosphorus increase its total control in shoots for both phases of growth. However, the amendment to soil gave better results than spraying leaves.

Which was the same as in the case of dry weight . this is may be due to the decrease of temperature during spraying, as confirmed by vally (1978)the Qrerious results showed on increase of dry weight of shoots, roots and whole plants when phosphorus is added in both used methods. This is may be due to the decrease of soils corent of soluble phosphorus in water, because of the increase of $\mathrm{P}^{\mathrm{H}}$. it is noted also the increase of dry weight plants growing in zone one soil than that of Telha, which is may be due to the high content of organic matter in the first. It is concluded from the previous results that , the addition of phosphorus to the growing plants, under Algerian condition is necessary .the temperature should be taken in consediration when phosphorus is sprayed on leaves.

Table 1 Some physical and chemical characteristics of the two soils under study

\begin{tabular}{|c|c|c|c|c|c|c|c|c|c|}
\hline \multirow[t]{2}{*}{ SOIL } & \multicolumn{4}{|c|}{ Size Distribution of soil articles } & \multirow{2}{*}{$\begin{array}{c}\% \\
\text { Humidity }\end{array}$} & \multirow{2}{*}{$\begin{array}{c}\mathrm{PH} \\
\text { Suspension } \\
1: 1\end{array}$} & \multirow{2}{*}{$\begin{array}{c}\mathrm{CaCO3} \\
\%\end{array}$} & \multirow{2}{*}{$\begin{array}{c}\text { Electric } \\
\text { conductivit } \\
y \\
\text { Mm hos / } \\
\mathrm{cm} \\
\text { at } 1925 \\
\end{array}$} & \multirow{2}{*}{$\begin{array}{c}\% \\
\text { Organic } \\
\text { matter }\end{array}$} \\
\hline & $\begin{array}{l}\text { Coarse } \\
\text { sand }\end{array}$ & $\begin{array}{l}\text { fine } \\
\text { sand }\end{array}$ & Salt & clay & & & & & \\
\hline $\begin{array}{c}\text { The First } \\
\text { Area }\end{array}$ & $2 ; 36$ & 12.53 & 25.55 & 59.56 & 33.73 & 7.75 & 25 & 1.00 & 3.52 \\
\hline Talha Area & 6.72 & 21.50 & 22.74 & 49.03 & 31.00 & 8.10 & 30 & 1.40 & 2.84 \\
\hline
\end{tabular}

Table 2 The effect of phosphorus on the vegetation measurements and varioliformis fresh during both phases of vegetative growth of wheat plants growing in soils the first area, Talha The first stage of growth The first stage of growth

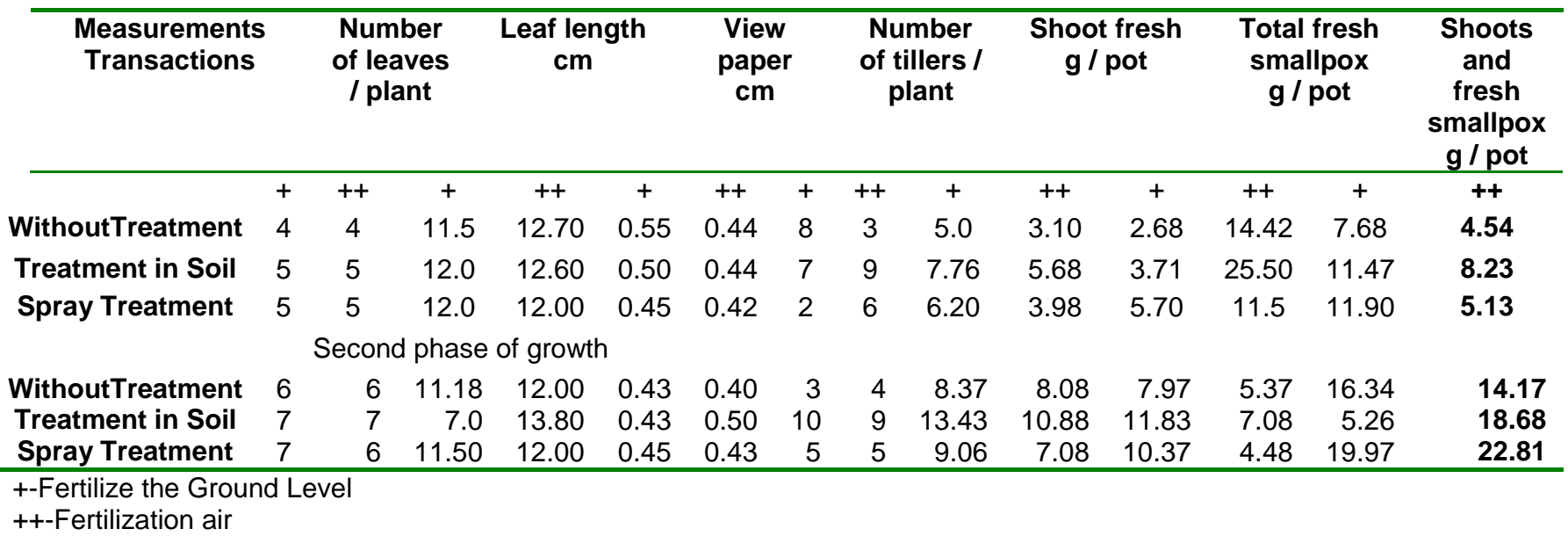


Agric. Biol. J. N. Am., 2013, 4(3): 300-308

Table 3 The effect of phosphorus in the soil and spraying on the leaves on the dry weight of both shoots and smallpox to the developing wheat plant soils in the region and the first two phases of growth Talha to the first and second

A - First stage of growth

The statistical analysis

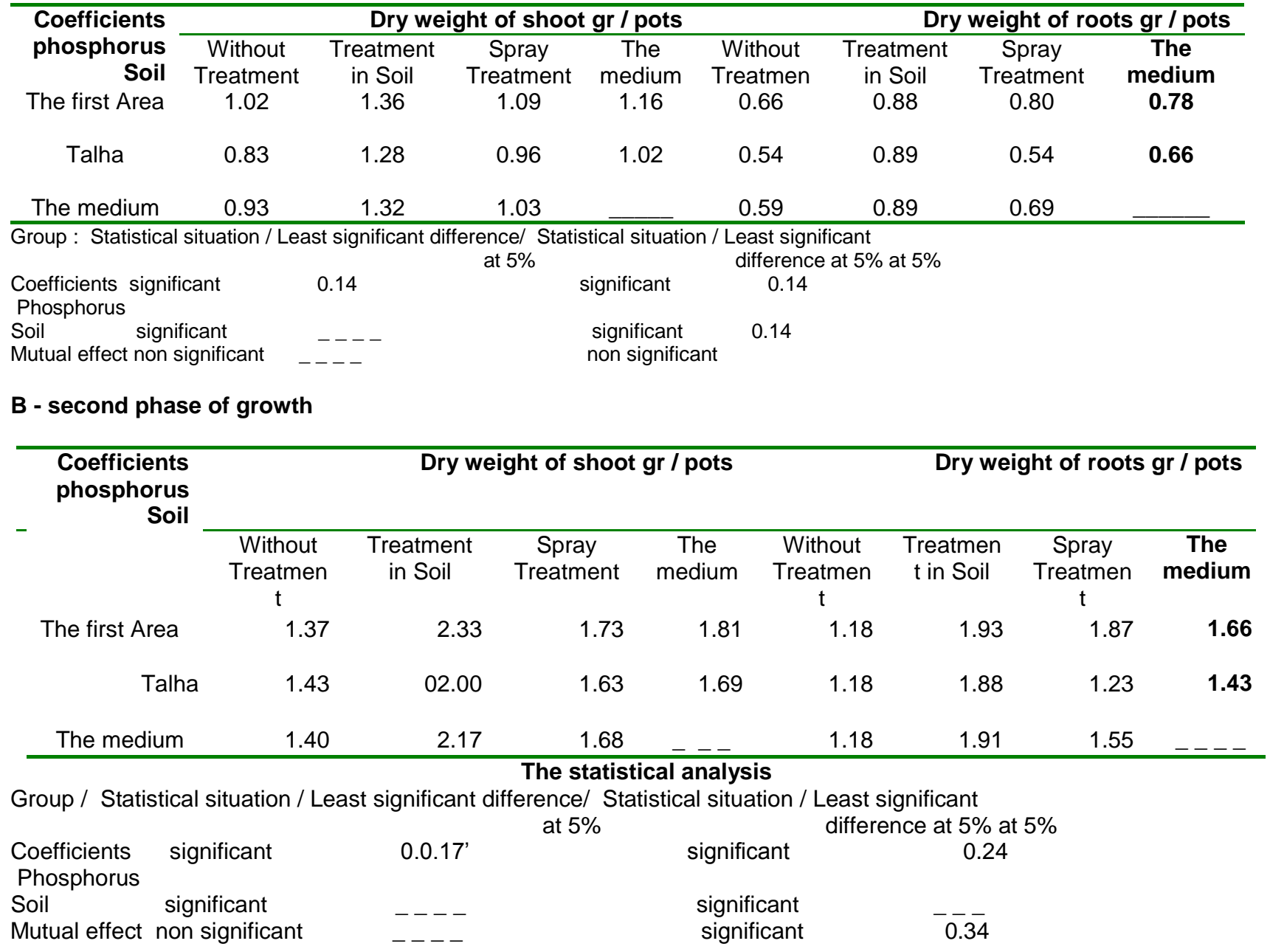


Agric. Biol. J. N. Am., 2013, 4(3): 300-308

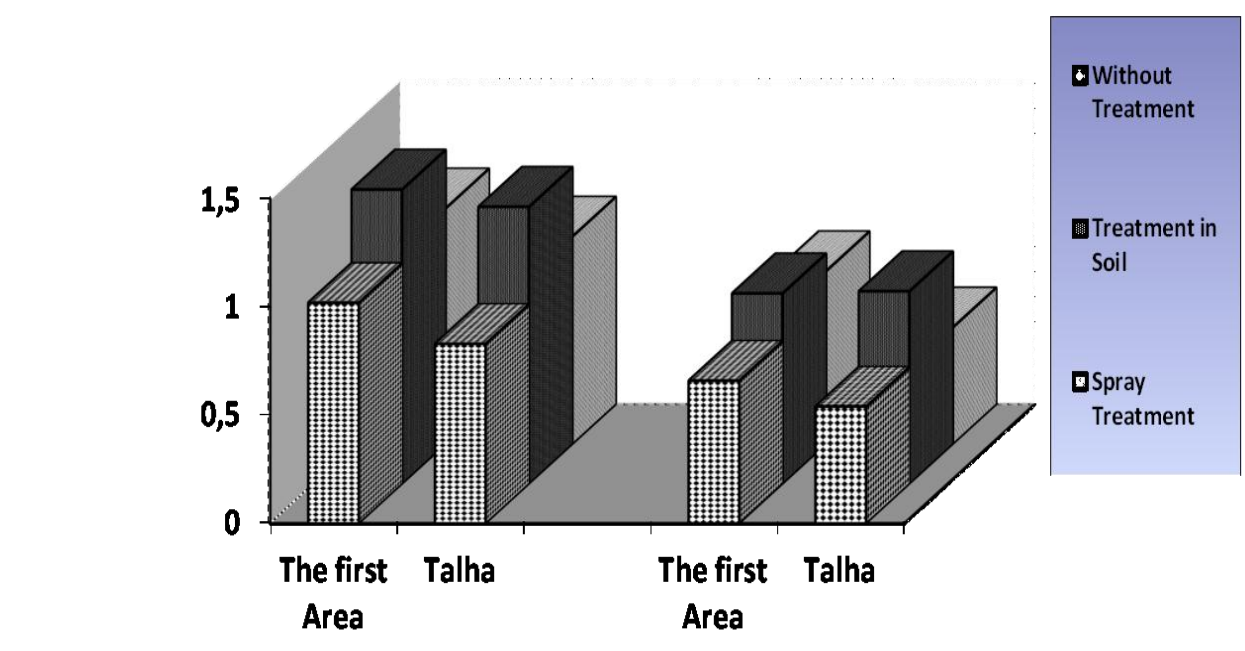

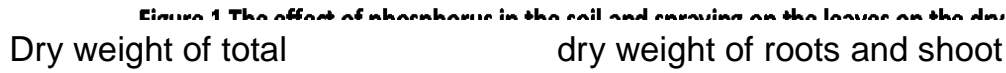

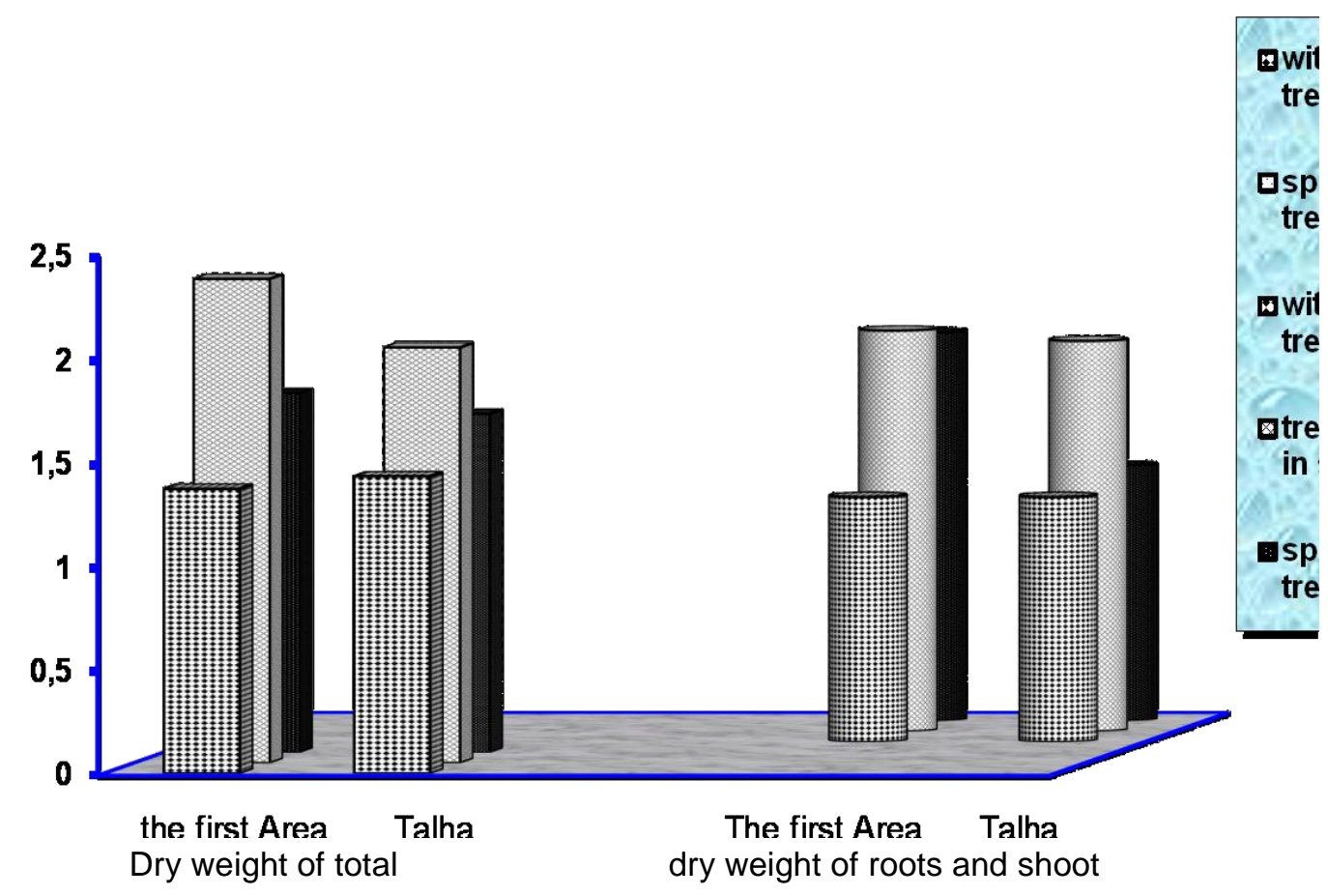


Agric. Biol. J. N. Am., 2013, 4(3): 300-308

Table 4 The effect of phosphorus in the soil and spraying on the leaves on the total dry weight of shoot + Total roots to the developing wheat plant soils in the region first and Talha for both phases of growth.

\begin{tabular}{lccccccc}
\hline Coefficients & Without & Treatment & Spray & The & Without & Treatment & Spray \\
phosphoru & Treatment & $\begin{array}{c}\text { Th Soil } \\
\text { Treatment }\end{array}$ & $\begin{array}{c}\text { medium } \\
\text { Treatment }\end{array}$ & in Soil & Treatment & medium
\end{tabular}

Soil Type

S

\begin{tabular}{rlccccccc}
\hline $\begin{array}{r}\text { The first } \\
\text { Area }\end{array}$ & 1.66 & 2.24 & 1.92 & 1.94 & 2.54 & 4.22 & 3.60 & 3.74 \\
Talha & 1.37 & 2.18 & 1.50 & 1.68 & 2.60 & 3.88 & 2.85 & 3.11 \\
The medium & 1.52 & 2.21 & 1.71 & & 2.57 & 4.08 & 3.23 & --- \\
\hline
\end{tabular}

The statistical analysis

Group / Statistical situation / Least significant difference/ Statistical situation / Least significant

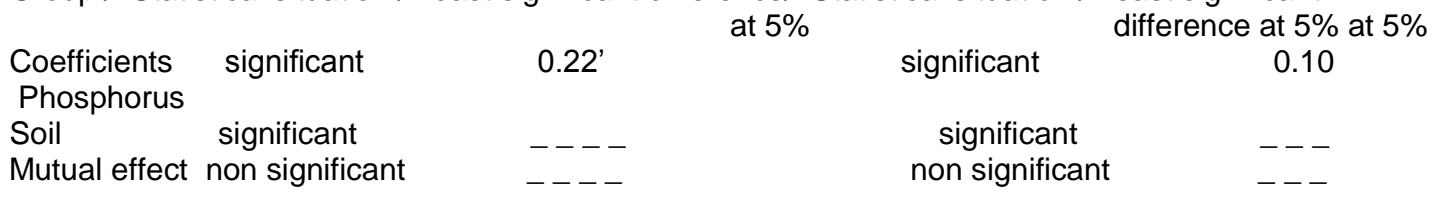

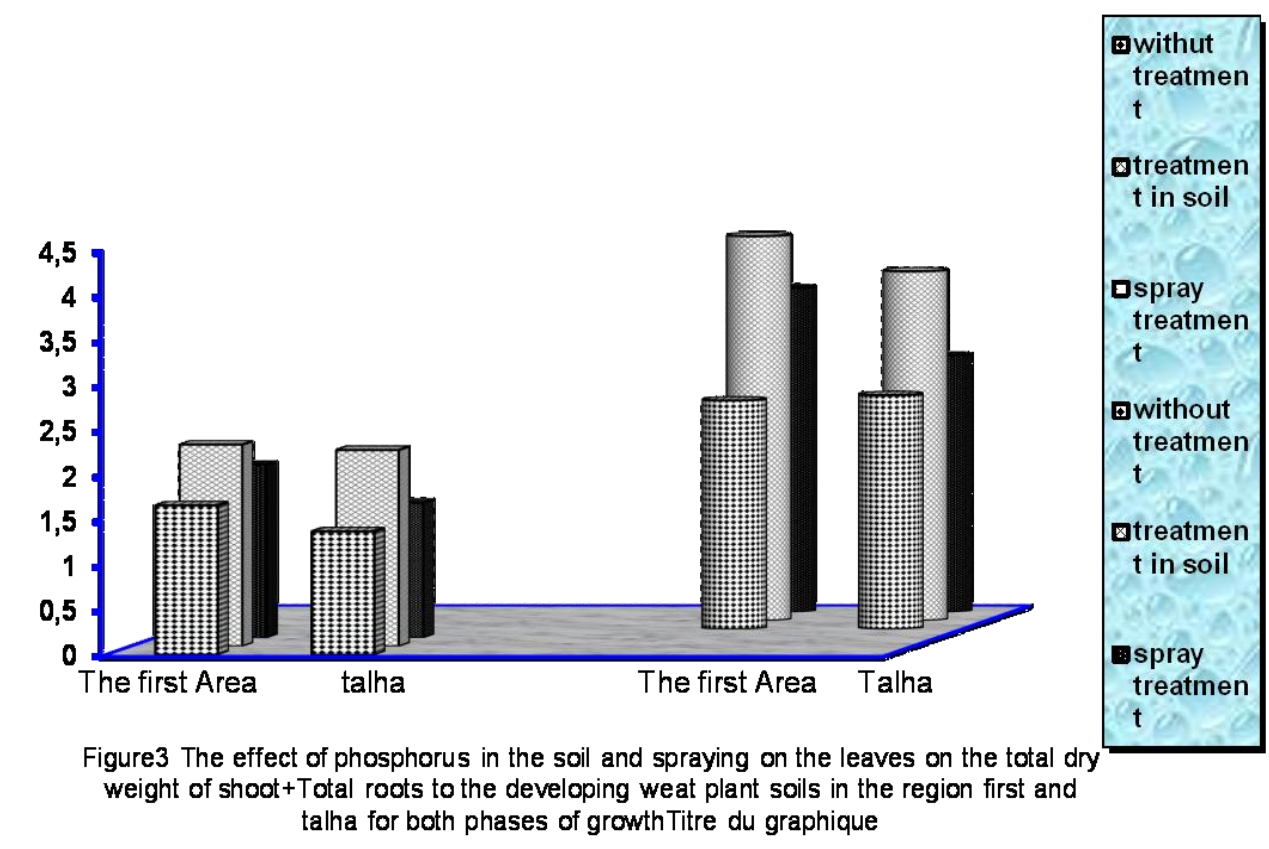

Second phase of growth

the first stage of growth 
Agric. Biol. J. N. Am., 2013, 4(3): 300-308

Table 5 Effect of phosphorus in the soil and spraying on the leaves in the region of the first and Talha on the amount of total phosphorus in shoots and roots to the wheat plant ( $\mathrm{mg} \mathrm{P}_{2} \mathrm{O}_{5}$ / pot) second phase of growth

\begin{tabular}{|c|c|c|c|c|c|c|}
\hline $\begin{array}{l}\text { Coefficients } \\
\text { phosphorus }\end{array}$ & \multicolumn{3}{|c|}{ Total vegetative } & \multicolumn{3}{|c|}{ Total roots } \\
\hline Soil & $\begin{array}{r}\text { Without } \\
\text { Treatment }\end{array}$ & $\begin{array}{r}\text { Treatment } \\
\text { in Soil }\end{array}$ & $\begin{array}{r}\text { Spray } \\
\text { Treatment }\end{array}$ & $\begin{array}{r}\text { Without } \\
\text { Treatment }\end{array}$ & $\begin{array}{r}\text { Treatment } \\
\text { in Soil }\end{array}$ & $\begin{array}{r}\text { Spray } \\
\text { Treatment }\end{array}$ \\
\hline The first & 4.34 & 11.63 & 5.09 & 2.27 & 2.55 & 3.07 \\
\hline Talha & 3.88 & 12.59 & 8.83 & 2.39 & 3.47 & 1.88 \\
\hline \multicolumn{7}{|c|}{ The first stage of growth } \\
\hline The first & 15.72 & 20.85 & 20.76 & 6.49 & 11.19 & 10.0 \\
\hline Talha & 9.44 & 22.4 & 11.41 & 9.79 & 13.54 & 39.0 \\
\hline
\end{tabular}

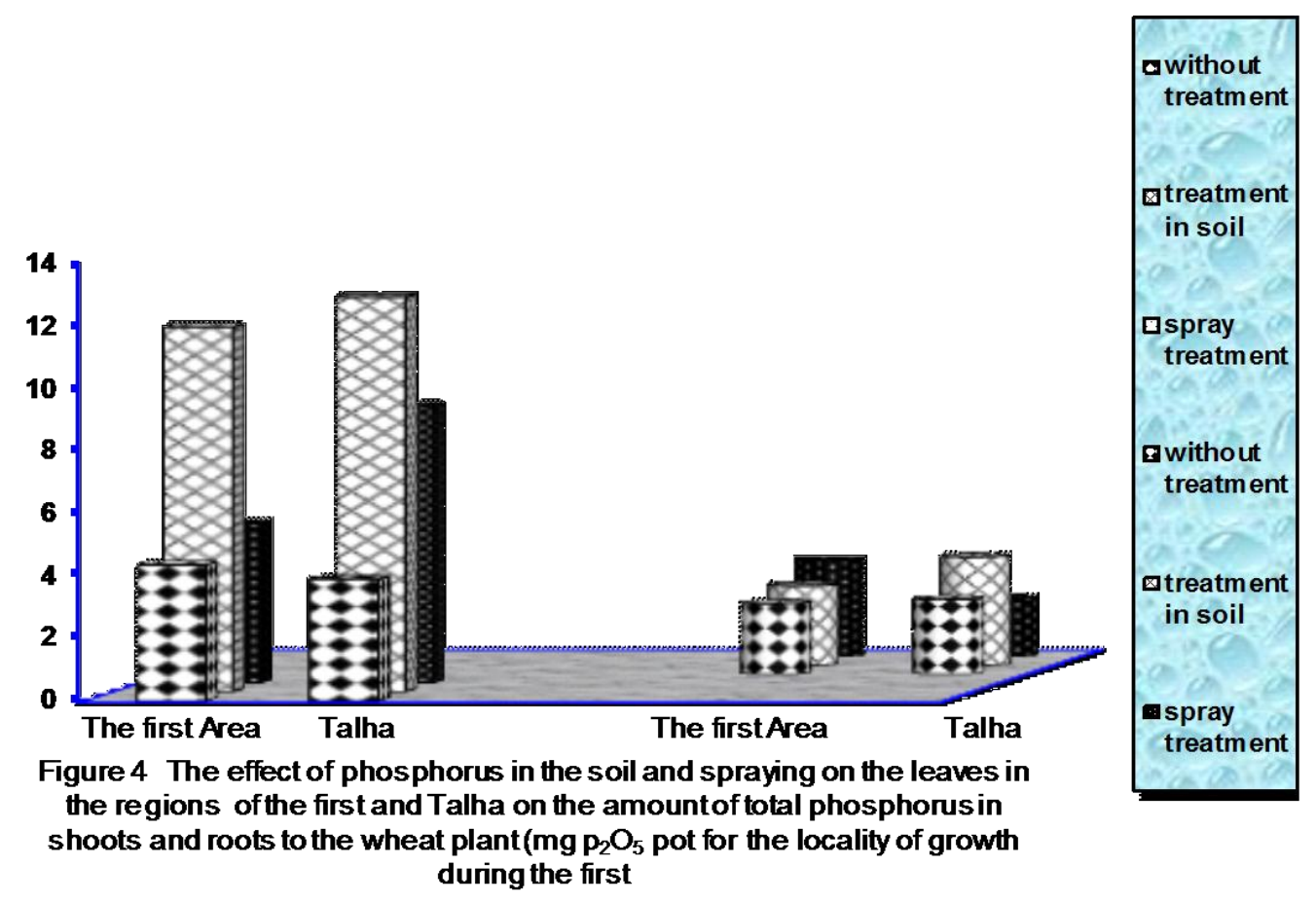

Second phase of growth

the first stage of growth 
Agric. Biol. J. N. Am., 2013, 4(3): 300-308

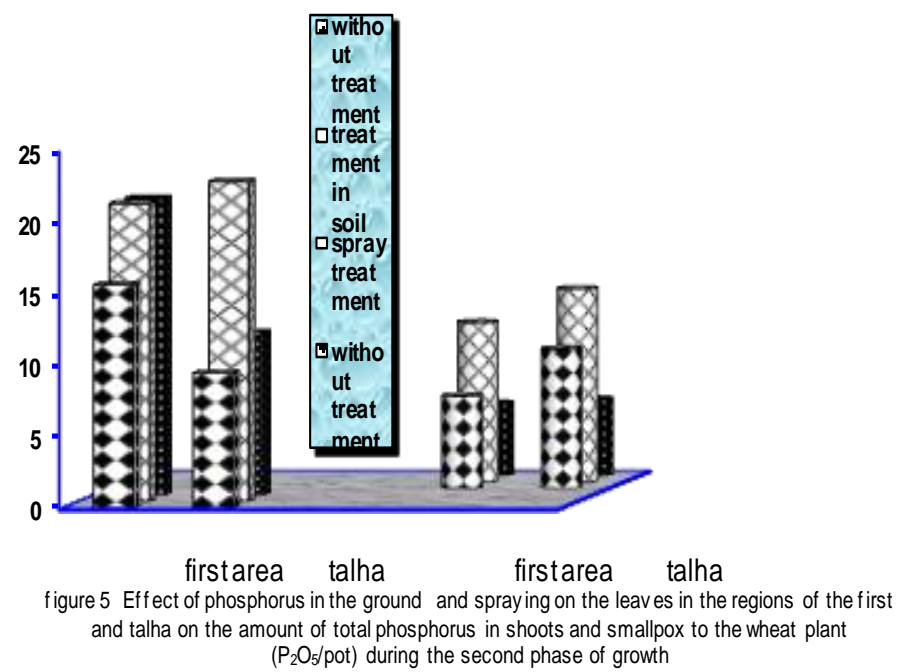

Second phase of growth the first stage of growth

Statistical Analysis

dry weight of roots

Dry weight of shoot

\begin{tabular}{|c|c|c|c|c|}
\hline Group & Statistical situation & $\begin{array}{c}\text { Least significant } \\
\text { difference at the level } \\
\text { of } 5 \%\end{array}$ & Statistical situation & $\begin{array}{c}\text { Least significant } \\
\text { difference at the level } \\
\text { of } 5 \%\end{array}$ \\
\hline $\begin{array}{l}\text { Transactions } \\
\text { phosphorus }\end{array}$ & $\begin{array}{l}\text { * } \text { significant } \\
\text { ** significant }\end{array}$ & $\begin{array}{l}0.14 \\
0.17\end{array}$ & $\begin{array}{l}{ }^{*} \text { significant } \\
\text { ** significant }\end{array}$ & $\begin{array}{l}0.13 \\
0.24\end{array}$ \\
\hline Soil & $\begin{array}{l}\text { * significant } \\
\text { ** significant }\end{array}$ & $\begin{array}{l}0.14 \\
0.17\end{array}$ & $\begin{array}{l}\text { * significant } \\
\text { ** significant }\end{array}$ & $\begin{array}{l}0.13 \\
0.24\end{array}$ \\
\hline Mutual influence & $\begin{array}{l}{ }^{*} \text { not significant } \\
{ }^{* *} \text { not significant }\end{array}$ & & $\begin{array}{l}{ }^{*} \text { not significant } \\
{ }^{* *} \text { not significant }\end{array}$ & ------- \\
\hline
\end{tabular}

Where: *-

The first stage of growth, ${ }^{* *}$ - second phase of growth

\section{REFERENCES}

Black ,C.A. (Ed) (1965) Methodes of Soil Analysis Part 2 : Chemical And Microbiological propertiers. American Socity Of Agronomy . Inc Publisher Madison .Wisconson.U.S.A

Brown and vanden Driessche,K.R.Brown and R.vanden Driessche,(2005) : Effect of nitrogen and phosphorus fertilization on the growth and nutrition of hybrid poplars on Vancouver Island, New For. 29.pp.89-104

Frei, E., Peyer, K And Schutz,E.(1964). Détermination of Phosphorus by scorbic Acid Schw. Landwirtsch For Schung Heft 3:318.

Fuehring,I.(1973). Response of grops Grown on Calcareaus 3 Soils to Fertilization. F.A.O Soil
Bulletin 21:53;

Hilal, M.H. Anter, F, And El Damaty,A,H,(1973). Chemical And Biological Approch tomard the definition of calcareaus soils. Movement and retation of P32 in soils as effected by parti sieze of Calcium carbonate Fraction. Agron.g.68,75.

Johnson,C.M.And Ulrich,S.(1959). Analytical Methodes for use in plant analysis California Agric, Experiments Sta.Bul 766:58.

Malakondajah.N.M.; Safaya, And Waly; M.C.(1981). Response of alfa alfa and barley to foliar application of $\mathrm{N}$ and $p$ on accalaminesoil plant and soil, 59.441- 
Agric. Biol. J. N. Am., 2013, 4(3): 300-308

Richards ,(1954). Dignosis and improvement of salin e and allcaline soils agriculture hand beek $N^{\circ} 60$ united states depertement of agriculture

Van den Driessche, R.vanden Driessche,F. Niemi and L Charleson,(2005): Fourth Year response of aspen seedling to lime, nitrogen and phosphorus applied at planting and one year after planting, for .

Ecol.Manage,219(2005).pp.216-228

Velly, J.(1978). Methodes of fertilizer application for increassing fertiluzer efficiancy .F.A.O soil Bull., 37/100 